\title{
PENGARUH KOMUNIKASI INTERPERSONAL GURU, STUDENT ENGAGEMENT DAN EFIKASI DIRI TERHADAP SCHOOL WELL-BEING SISWA SMPN 1 SEMANU KABUPATEN GUNUNGKIDUL
}

\author{
Kuswoyo, Nurul Hidayah dan Ahmad Muhammad Diponegoro \\ Universitas Ahmad Dahlan Yogyakarta, Indonesia \\ Email: kuswoyoaji78@gmail.com, bnurul.hidayah@psy.uad.ac.id \\ dan cahmad.diponegoro@psy.uad.ac.id
}

\begin{tabular}{l} 
INFO ARTIKEL \\
\hline Diterima \\
21 Februari 2021 \\
Direvisi \\
2 Maret 2021 \\
Disetujui \\
15 Maret 2021 \\
\\
Keywords \\
self-efficacy; teacher interpersonal \\
communication; school well-being; \\
students; student-engagement
\end{tabular}

\section{ABSTRACT}

This study aims to 1) test the influence between teacher interpersonal communication, student engagement and self-efficacy on school well-being. 2) test the influence of teacher interpersonal communication on school wellbeing. 3) test the influence of student engagement on school well-being. 4) test the effect of self-efficacy on well-being schools. The population is students of SMP Negeri 1 Semanu Gunungkidul Regency. The research sample was grade VI A, VIII C and IX A students who numbered 95 students. Sampling techniques use cluster random sampling. The data collection method uses a research instrument consisting of four research scales, namely the school well-being scale, the teacher interpersonal communication scale, the student engagement scale and the self-efficacy scale. The data analysis technique used is multiple regression analysis with the help of SPSS 25.0. The results of this study are 1) there is a very significant influence between teacher interpersonal communication, student engagement and self-efficacy towards school well-being, with a value of significance $=0.000<(0.01)$, a value of $F$ of 35,880 and a value of $R=0.542$. 2) there is a positive and very significant influence between teacher interpersonal communication towards school well-being with significance value $=0.000<0.01$ and value $t=3.777 .3$ ) there is a positive and significant influence between student engagement towards school well-being with significance value $=0.027<0.05$ and value $t=2.246 .4$ ) there is a positive and very significant influence between students' self-efficacy towards well-being school with significance value $=0.000<0.01$ and $t$ value $=4.973$.

\footnotetext{
ABSTRAK

Penelitian ini bertujuan untuk 1) menguji pengaruh antara komunikasi interpersonal guru, student engagement dan efikasi diri terhadap school well-being. 2) menguji pengaruh komunikasi interpersonal guru terhadap school well-being. 3) menguji pengaruh student engagement
} 
Kata Kunci:

efikasi diri; komunikasi interpersonal guru; school wellbeing; siswa; student-engagement terhadap school well-being. 4) menguji pengaruh efikasi diri terhadap school well-being. Populasi adalah siswasiswi SMP Negeri 1 Semanu Kabupaten Gunungkidul. Sampel penelitian adalah siswa kelas VI A, VIII C dan IX A yang berjumlah 95 siswa. Teknik sampling menggunakan cluster random sampling. Metode pengumpulan data menggunakan istrumen penelitian yang terdiri dari empat skala penelitian, yaitu skala school well-being, skala komunikasi interpersonal guru, skala student engagement dan skala efikasi diri. Tehnik analisis data yang digunakan adalah analisis regresi berganda dengan bantuan SPSS 25.0. Hasil penelitian ini adalah 1) ada pengaruh yang sangat signifikan antara komunikasi interpersonal guru, student engagement dan efikasi diri terhadap school well-being, dengan nilai signifikansi $=0,000<(0,01)$, nilai $\mathrm{F}$ sebesar 35,880 dan nilai $\mathrm{R}=0,542$. 2) ada pengaruh positif dan sangat signifikan antara komunikasi interpersonal guru terhadap school well-being dengan nilai signifikansi $=0,000<$ 0,01 dan nilai $t=3,777$. 3) ada pengaruh positif dan signifikan antara student engagement terhadap school well-being dengan nilai signifikansi $=0,027<0,05$ dan nilai $\mathrm{t}=2,246$. 4) ada pengaruh positif dan sangat signifikan antara efikasi diri siswa terhadap school wellbeing dengan nilai signifikansi $=0,000<0,01$ dan nilai $\mathrm{t}$ $=4,973$.

\section{Pendahuluan}

Sekolah dengan seluruh perangkat di dalamnya merupakan institusi yang memiliki peran penting dalam upaya mencapai tujuan pendidikan nasional. Undang-undang Nomor 20 Tahun 2003 tentang Sistem Pendidikan Nasional mengisyaratkan bahwa tujuan pendidikan nasional adalah berkembangnya potensi peserta didik. (Karyani, U., Prihartanti, N., Dinar, W., Lestari, R., Hertinjung, W. S., Prasetyaningrum, J., Partini, 2015) menyatakan sekolah diharapkan mampu mengemban tujuan pendidikan tersebut sehingga berhasil memberikan pengalaman terbaik bagi siswa yang pada akhirnya membuat siswa-siswanya
Coresponden Author

Email: kuswoyoaji78@gmail.com Artikel dengan akses terbuka dibawah lisensi

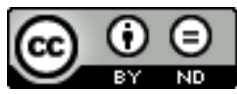


terhadap penyerapan pengetahuan melainkan juga tempat menempa diri pada pengetahuan non akademis terutama pada penajaman soft skill peserta didik, sebagai usaha pencapaian cita-cita (Setyawan \& Dewi, 2015).

Remaja dalam posisinya sebagai pelajar sekolah menengah pertama memiliki keunikan tersendiri terkait pandangan terhadap kesejahteraan sekolah. Remaja SMP merupakan remaja awal dalam rentang usia rata-rata 11-14 tahun yang dalam perkembangan fisik dan psikologisnya sedang mengalami masa transisi. Perkembangan pesat pada sisi fisik dan hormonnya berdampak pada perkembangan kejiwaannya sehingga remaja SMP sering mengalami gejolak. (Hurlock et al., 2002) mengatakan bahwa usia remaja merupakan sebuah masa yang penting. Hal ini disebabkan karena masa tersebut merupakan periode peralihan, masa perubahan, usia penuh masalah, masa mencari identitas, dan usia yang menimbulkan ketakutan. Menurut (Sarwono, 2012) usia remaja merupakan masa di mana terjadi topan dan badai dalam kehidupannya. Perkembangan pesat sosio-emosionalnya harus dibenturkan dengan kenyataan terhadap adanya nilai-nilai yang menyebabkan remaja emosinya meledak-ledak dan sering terjadi konflik baik dalam internal pribadinya maupun konflik dalam relasi sosialnya. Konflik di ranah relasi sosial harus dihadapi remaja tidak terkecuali di lingkungan sekolahnya. Remaja harus berusaha keras menyesuaikan diri untuk mendapatkan lingkungan sekolah nyaman dan sejahtera.

Keberhasilan sekolah dalam usaha pencapaian tujuan pendidikan tersebut bergantung pada bagaimana sekolah dengan peran strategisnya mampu menciptakan lingkungan yang positif bagi perkembangan emosi dan sosial siswa-siswanya, di samping kontribusinya pada keunggulan akademis. Sekolah harus mampu membuat siswa sejahtera dalam proses kegiatan belajar mengajar di dalamnya. Kondisi sekolah yang tidak menyenangkan, menekan, dan membosankan akan berakibat pada pola siswa yang bereaksi negatif, seperti stres, bosan, terasingkan, kesepian dan depresi. Kondisi tersebut akan berdampak pada penilaian individu terhadap sekolahnya (Khatimah, 2015). Hal ini sesuai dengan penelitian (Huebner \& McCullough, 2000) yang menyatakan sumber stres yang signifikan dan berkurangnya kualitas hidup peserta didik dapat disebabkan oleh pengalaman sekolah yang kurang menyenangkan.

Sekolah yang sejahtera dapat dilihat dari bagaimana siswa menilai keadaan sekolah mereka sendiri dan bagaimana peran sekolah dalam proses belajar mereka. Siswa yang menunjukkan kecintaan terhadap sekolah mereka, cenderung lebih baik dan juga lebih sehat (Papalia et al., 2008). Sekolah merupakan lembaga sosial yang kuat dan potensial sebagai sarana atau tempat perkembangan sosial remaja. Sekolah juga merupakan sarana yang potensial dalam membentuk kepribadian individu serta konsep sosial yang baik yang akhirnya akan memberikan kesejahteraan itu sendiri terhadap siswa (Tian et al., 2016).

(Duckett et al., 2010) dalam penelitiannya menjelaskan bahwa konsep kesejahteraan siswa berawal dari asumsi bahwa jika anggota sekolah merasa senang dan aman di sekolah, siswa akan mengaktualisasikan potensinya. Kesejahteraan sekolah merupakan kondisi sekolah di mana terdapat hubungan timbal balik rasa hormat antara anggota sekolah. Hubungan tersebut bertujuan meminimalisir konflik di antara mereka sehingga dapat mempertahankan kondisi seimbang, berkeadilan, dan menonjolkan kerja keras untuk mencapai prestasi pribadi dan sosial (Duckett et al., 2010).

Keberhasilan sekolah dalam usaha menyejahterakan siswanya dapat dilihat dari konsep yang dinamakan school well-being (kesejahteraan sekolah). Menurut (Kraag et 
al., 2006) School well-being adalah kepuasan siswa untuk memenuhi kebutuhan dasar di sekolah yang meliputi having (kondisi sekolah), loving (hubungan sosial), being (pemenuhan diri), dan health (status kesehatan). (Kraag et al., 2006) mengembangkan model kesejahteraan sekolah dengan mengadopsi teori sosiologi mengenai kesejahteraan (welfare) dipadukan dengan konsep sejahtera (well-being) dalam entitas sekolah, sehingga kesejahteraan dikaitkan dengan pengajaran (teaching), pendidikan (education), belajar (learning) dan prestasi (achievement).

(Kraag et al., 2006) menyebutkan terdapat empat dimensi terkait dengan kesejahteraan siswa di sekolah yaitu: Having yaitu kondisi sekolah baik pada aspek fisik, organisasi, layanan maupun keamanan. Loving yaitu relasi sosial terhadap sesama peserta didik, guru, maupun staf sekolah. Being yaitu pemenuhan diri berupa kesempatan belajar sesuai dengan kapabilitas, mendapatkan umpan balik, dan semangat dan Health yaitu status kesehatan.

Observasi awal dan wawancara peneliti terhadap lima belas siswa SMPN 1 Semanu pada tanggal 11 sampai dengan 13 November 2019 mendapatkan fakta bahwa kenyamanan dan kesejahteraan belum maksimal dirasakan oleh siswa. Kebersihan lingkungan masih banyak dikeluhkan termasuk kebersihan toilet sekolah di samping sampah masih menjadi masalah yang cukup meresahkan baik di dalam kelas maupun sekitar kelas. Tampungan air tidak tersedia sehingga jika air PDAM mati dampaknya sangat dirasakan oleh siswa. LCD sarana pembelajaran yang sudah tidak terpasang lagi di tempatnya menjadi pertanyaan banyak siswa. Dimensi Having lain yang ditemukan peneliti adalah debu yang menempel pada sebagian besar kaca di seluruh bangunan sekolah dan sebagian besar pintu tidak lagi berfungsi sehingga jika selesai pembelajaran pintupintu tidak dikunci.
Relasi sosial sebagai representasi dimensi loving pada school well-being siswa menunjukkan fakta tidak terlalu bagus. Hasil wawancara dan observasi daftar kasus yang ditangani guru BK menunjukkan ketidak harmonisan siswa dan guru dalam hal pemberian hukuman terhadap pelanggar tata tertib. Pertikaian sesama siswa juga sering terjadi. Masalah pada dimensi being ditunjukkan oleh keluhan siswa atas tidak berjalannya ekstrakurikuler sebagaimana jadwal yang ditetapkan. Kasus terakhir terkait proses pembelajaran justru datang dari kritikan orangtua siswa terhadap aktivitas pembelajaran yang tidak maksimal sehingga self fulfilment siswa tidak tersalurkan dengan baik. Keluhan sakit dan banyaknya daftar siswa yang masuk ke UKS menunjukkan dimensi health dari school well-being siswa belum maksimal.

Konsep school well-being sangat bermanfaat dan menjadi konsepsi yang penting diaplikasikan di sekolah.

(Kraag et al., 2006) menjelaskan bahwa siswa dapat belajar secara efektif dan memberi sumbangan positif pada sekolah jika dalam proses tersebut siswa sehat secara fisik, merasa bahagia dan sejahtera dalam mengikuti proses kegiatan belajar mengajar di kelas. School well-being bermanfaat untuk menciptakan lingkungan pembelajaran yang kondusif, yang pada akhirnya mampu mencapai tujuan pembelajaran tersebut.

Sekolah dapat menjadikan school wellbeing sebagai acuan dalam rangka memahami dan menyediakan fasilitas-fasilitas yang membuat siswa merasa nyaman dan sejahtera berada di dalam keseluruhan aktivitas pembelajaran di sekolah. Pandangan subjektif siswa mengenai sekolahnya dapat dijadikan terobosan evaluasi dan pengembangan sekolah (Kraag et al., 2006).

Relasi sosial siswa terhadap guru merupakan faktor penting bagi terciptanya kesejahteraan dan kepuasan siswa dalam aktivitas belajar-mengajar di sekolah. Relasi 
sosial ini tercermin dari komunikasi interpersonal yang terjalin antara siswa dan guru. Interaksi guru dan siswa merupakan proses komunikasi timbal balik dan membentuk hubungan yang sangat erat. Keberlangsungan proses belajar-mengajar yang efektif banyak ditentukan oleh faktor komunikasi.

(Sabo, 1995) dalam penelitiannya mengungkapkan bahwa ketika murid ditanya bagaimana mereka menyukai sekolah, maka jawabannya bahwa kesukaan mereka terhadap sekolah sebagaimana mereka menyukai guru mereka. Penelitian Lohre 2010 mendukung hasil penelitian ini bahwa nilai tertinggi kepuasan sekolah siswa ada pada kesukaan mereka terhadap guru-gurunya. Oleh karena pentingnya komunikasi interpersonal guru ini, peneliti menjadikannya sebagai prediktor utama dalam perannya terhadap school wellbeing.

(Rakhmat, 2009) mendefinisikan komunikasi interpersonal sebagai proses pertukaran makna antara individu dengan individu lain yang dilakukan secara timbal balik serta mempengaruhi perubahan sikap maupun perilaku dalam pencapaian tujuan yang diinginkan. (Rakhmat, 2009) juga mengatakan bahwa terjalinnya komunikasi interpersonal apabila menunjukkan adanya pemahaman yang sama atas pesan yang disampaikan oleh guru dengan siswa. Kejelasan guru dalam menyampaikan informasi akan bepengaruh terhadap pemahaman siswa ketika tidak mengerti mencapai tujuan belajar dan membantu memberikan informasi tentang sasaran tujuan belajar, penguatan-penguatan, evaluasi dan keberhasilan belajar, menyebabkan siswa semakin sadar akan kemampuan dirinya.

Menurut (Devito, 2016) komunikasi interpersonal merupakan proses penyampaian pesan antara dua orang yang memiliki hubungan interpersonal, misalnya antara orangtua-anak, antar teman, antar saudara, guru-siswa, atasan-bawahan,dokter-pasien, atau hubungan profesional atau nonprofesional lain. (Devito, 2016) juga menjelaskan komunikasi interpersonal sebagai komunikasi verbal dan non verbal yang terjadi ketika individu melakukan interaksi dengan orang lain. Interaksi tersebut mengajarkan individu untuk memahami dirinya sendiri dan lawan komunikasinya, serta mengungkapkan dirinya terhadap orang lain. Individu dapat memulai, memelihara, atau memperbaiki hubungan interpersonalnya dengan orang lain untuk mencapai komunikasi interpersonal yang efektif.

Komunikasi interpersonal guru yang efektif mampu meningkatkan berbagai hal berkenaan dengan aktivitas belajar-mengajar di sekolah yang bermuara terhadap terciptanya kesejahteraan siswa di sekolah tersebut. Penelitan kualitatif (Alang, 2018) menghasilkan fakta bahwa komunikasi interpersonal guru mampu meningkatkan keaktifan belajar. Penelitian (Rianatha \& Sawitri, 2015) menyatakan adanya hubungan positif yang signifikan antara komunikasi interpersonal guru-siswa dan Self Regulated Learning (SRL). Hal ini berarti bahwa semakin baik komunikasi interpersonal gurusiswa maka semakin tinggi Self Regulated Learning-nya. Kesejahteraan sekolah secara umum bisa dilihat dari hubungan dan komunikasi antara guru dan siswa. Kesejahteraan guru menentukan kesejahteraan siswa (Roffey, 2012).

Kegiatan belajar mengajar adalah proses menuntut interaksi yang fleksibel antara siswa dan guru. Peran guru dan cara guru berinteraksi dengan siswa sangat penting diperhatikan untuk efektifitas belajar mengajar. Efektifnya keberfungsian lingkungan belajar sangat dipengaruhi oleh interaksi antara guru dan siswa. Kerja sama dan saling ketergantungan menjadi penting dilakukan oleh karena dampak dari interaksi tersebut. Hubungan interpersonal dan saling percaya antara guru dan siswa sangat signifikan menciptakan school well-being 
(Hongwidjojo et al., 2018). Suasana relasional yang positif dianggap penting dalam memfasilitasi keharmonisan pengembangan dan motivasi siswa. Dengan demikian peningkatan hasil kognitif dan afektif siswa untuk pencapaian tujuan pendidikan dapat ditingkatkan dengan aspek komunikasi interpersonal guru dan siswa di lingkungan kelas (Van Petegem et al., 2005).

Student engagement merupakan Faktor lain yang berkorelasi terhadap school wellbeing. (O'Brien, 2008) memasukkan student engagement sebagai faktor eksternal pembentuk school well-being. Alsa, Haq, Siregar, Kusumaningrum, (Alsa et al., 2015) menjelaskan student engagement sebagai salah satu faktor pembentuk school wellbeing dari dimensi being. (Fredricks et al., 2004) mendefinisikan student engagement sebagai suatu keterlibatan siswa dalam aktivitas akademik maupun non akademik (sosial dan ekstrakurikuler) di sekolah maupun kelas.

Penelitian (Aisah, 2018) mengenai hubungan school well-being dengan student engagement mengasilkan kesimpulan adanya hubungan yang signifikan antara school wellbeing dengan student engagement. Semakin tinggi school well-being semakin tinggi pula student engagement, hal ini juga menunjukkan bahwa semakin rendah school well-being semakin rendah pula student engagement. Keterlibatan siswa yang mencakup seluruh domain baik, kognitif, emosi dan perilaku memiliki hubungan yang kuat dengan prestasi akademik, terlebih terhadap keterlibatan kognitif dan perilaku (Gunuc, 2014).

Student engagement memiliki konstruksi multidimensional yang dibagi ke dalam tiga dimensi yaitu; behavioral engagement, emotional engagement, dan cognitive engagement (Fredricks et al., 2004). Behavioral engagement merupakan sebuah partisipasi siswa yang meliputi keterlibatan dalam kegiatan dibidang akademik, sosial maupun ekstrakurikuler. Hal ini dapat menunjang siswa untuk mencapai keberhasilan dalam akademik. Emotional engagement merujuk kepada reaksi afektif siswa di dalam kelas, termasuk ketertarikan, kebosanan, kesenangan, kesedihan, dan emotional engagement merupakan reaksi positif dan negatif terhadap guru, teman sekelas, akademik, dan sekolah. Emotional engagement sendiri dapat memunculkan ikatan siswa dengan sekolah dan akan memengaruhi siswa untuk melakukan tugas sekolah tanpa adanya suatu keterpaksaan. Cognitive engagement yaitu penggabungan perhatian dengan kemauan siswa dalam menghadapi tugas sekolah yang dirasa sulit (Fredricks et al., 2004).

(Reeve, 2005) menjelaskan student engagement memiliki empat peran dalam proses belajar. Pertama, student engagement membuat proses belajar mungkin dilakukan danmerupakan syarat dari pengalaman pembelajaran yang produktif. Kedua, Student engagement dapat memprediksi seberapa baik peserta didik menempuh proses belajarnya, terutama dari pencapaian mereka (ranking dan nilai ujian) dan kelulusan mereka (apakah dikeluarkan dari institusi tempat mereka belajar atau tidak). Ketiga, student engagement dapat memberikan pertimbangan kepada institusi pendidikan mengenai intervensi yang dapat dilakukan kepada para pembelajar agar proses belajar mereka semakin baik. Keempat, student engagement memberikan feedback terhadap pengajar untuk menentukan telah seberapa baik usaha mereka dalam memotivasi para siswa dalam proses belajar mereka. Keempat peran student engagement di atas merupakan hal yang positif bagi terciptanya school well-being siswa yang akhirnya dapat menentukan keberhasilan proses pembelajaran.

Faktor penting lain untuk mengungkapkan pentingnya school wellbeing adalah efikasi diri siswa. Keyes dan Waterman (Khatimah, 2015) mengemukakan 
salah satu faktor yang dapat memengaruhi school well-being adalah karakteristik pribadi. Efikasi diri merupakan salah satu unsur kepribadian (A Bandura, 1997). (Albert Bandura, 1995) mengatakan bahwa efikasi diri adalah kepercayaan diri dalam kemampuan seseorang untuk mengatur dan melaksanakan tindakan yang diperlukan untuk mengelola situasi tertentu. (A Bandura, 1997) mengungkapkan bahwa perbedaan efikasi diri dalam setiap individu terletak pada tiga aspek, yaitu level, strength, dan generality. Bandura menjelaskan empat sumber efikasi diri antara lain: (1). Mastery experience, yaitu pengalaman-pengalaman tentang penguasaan, (2). Vicarious Experience yaitu pengalaman-pengalaman yang dialami orang lain, (3). Social Persuation, yaitu persuasi sosial, dan (4) Physical and Emotional States, yaitu kondisi fisiologis dan emosi (Feist, \& Feist, 2008).

Efikasi diri siswa memiliki pengaruh terhadap terciptanya well-being di sekolah. Penelitian (Firmanila \& Sawitri, 2015) tentang hubungan antara efikasi diri akademik dan school well-being menghasilkan kesimpulan adanya hubungan yang positif antara efikasi diri dan school well-being. Penelitian lain (Nanda \& Widodo, 2015) menghasilkan kesimpulan adanya hubungan positif yang signifikan antara school wellbeing dengan efikasi diri siswa. Semakin tinggi school well-being, maka semakin tinggi pula efikasi diri siswanya, dan sebaliknya, semakin rendah school wellbeing, maka semakin rendah efikasi diri siswanya.

Analisis peneliti berdasarkan paparan tentang school well-being di atas dan fakta yang terjadi di lapangan, maka penulis mengidentifikasi bahwa faktor penting yang akan diangkat dalam penelitian mengenai school well-being ini adalah komunikasi interpersonal guru, student engagement dan efikasi diri siswa. Oleh karena itu penulis ingin mengetahui apakah ada pengaruh komunikasi interpersonal guru, student engagement dan efikasi diri terhadap school well-being siswa SMP Negeri 1 Semanu.Tujuan dalam penelitian ini yaitu untuk menguji pengaruh komunikasi interpersonal guru, student engagement, dan efikasi diri terhadap school well-being. Hipotesis dalam penelitian ini adalah: 1) terdapat pengaruh komunikasi interpersonal guru, student engagement, dan efikasi diri terhadap school well-being. 2) terdapat pengaruh komunikasi interpersonal guru terhadap school well-being. 3) terdapat pengaruh student engagement terhadap school well-being.4) terdapat pengaruh efikasi diri terhadap school well-being.

\section{Metode Penelitian}

Metode untuk menganalisis data penelitian menggunakan metode statistik parametrik. Analisis data dilakukan dengan menggunakan SPSS 25 melalui teknik uji regresi berganda linier (multiple regression) yaitu suatu teknik analisis statistik untuk mengetahui peran antara dua variabel bebas (komunikasi interpersonal guru, student engagement dan efikasi diri) dengan satu variabel tergantung (school well-being). Uji asumsi yang dilakukan sebelum uji hipotesis adalah uji normalitas, uji linieritas dan uji multikolinearitas.

Populasi adalah siswa-siswi SMP Negeri 1 Semanu Kabupaten Gunungkidul tahun pelajaran 2019/2020. Sampel penelitian adalah siswa kelas VI A, VIII C dan IX A yang berjumlah 95 siswa. Teknik pengambilan sampel penelitian dengan menggunakan teknik cluster random sampling.

\section{Hasil dan Pembahasan}

\section{A. Uji Prasyarat}

\section{Uji Normalitas}

Uji normalitas bertujuan untuk melihat normal atau tidaknya distribusi sebaran skor subjek pada variabel 
school well-being, komunikasi interpersonal guru, student engagement dan efikasi diri. Uji normalitas dilakukan dengan menggunakan one sample-kolmogorov-smirnov Test. Hasil analisis menunjukkan bahwa ketiga variabel memiliki sebaran yang normal yang dapat dilihat tabel 1 dibawah ini.

\section{Tabel 1}

Hasil Uji Normalitas Data

\begin{tabular}{llll}
\hline Variabel & $\begin{array}{l}\text { Kolmogrov- } \\
\text { Smimov Z }\end{array}$ & $\begin{array}{l}\text { Sig } \\
(\mathrm{p})\end{array}$ & $\begin{array}{l}\text { Keteran } \\
\text { gan }\end{array}$ \\
\hline $\begin{array}{l}\text { School Well- } \\
\text { Being }\end{array}$ & 0,979 & 0,203 & Normal \\
\hline $\begin{array}{l}\text { Komunikasi } \\
\text { Interpersonal } \\
\text { guru }\end{array}$ & 0,804 & 0,538 & Normal \\
\hline $\begin{array}{l}\text { Student- } \\
\text { Engagement } \\
\text { Efikasi Diri }\end{array}$ & 0,841 & & \\
\hline
\end{tabular}

\section{Uji Linieritas}

Hasil uji linearitas di peroleh dilihat nilai $\mathrm{p}$-linierity masing-masing sebesar 0,000 $(\mathrm{p}<0,05)$ dan $\mathrm{p}$-deviation masing-masing sebesar $0,134,0,109$ dan 0,0,122 ( $>0,05)$, maka dapat disimpulkan bahwa antar masingmasing variabel bebas dengan variabel tergantung memiliki hubungan yang linier. Hasil uji linearitas yang dapat dilihat pada tabel 2 dibawah ini.

Tabel 2

Uji linieritas

\begin{tabular}{|c|c|c|c|c|c|}
\hline \multirow[t]{2}{*}{ Variabel } & \multicolumn{2}{|c|}{ Linierity } & \multicolumn{2}{|c|}{$\begin{array}{c}\text { Dev. From } \\
\text { linierity }\end{array}$} & \multirow[t]{2}{*}{ Ket. } \\
\hline & $\mathbf{F}$ & $\begin{array}{c}\mathrm{Si} \\
\mathbf{g} \\
(\mathbf{p})\end{array}$ & $\mathbf{F}$ & $\begin{array}{l}\text { Sig } \\
(p)\end{array}$ & \\
\hline $\begin{array}{l}\text { School well-being } \\
\text { terhadap } \\
\text { komunikasi } \\
\text { interpersonal guru }\end{array}$ & $\begin{array}{c}49,1 \\
62\end{array}$ & $\begin{array}{l}0.0 \\
00\end{array}$ & 1,413 & 0,134 & Linier \\
\hline $\begin{array}{l}\text { School well-being } \\
\text { terhadap student } \\
\text { engagement }\end{array}$ & $\begin{array}{c}39,1 \\
45\end{array}$ & $\begin{array}{c}0,0 \\
00\end{array}$ & 1,465 & 0,109 & Linier \\
\hline $\begin{array}{l}\text { School well-being } \\
\text { terhadap efikasi } \\
\text { diri }\end{array}$ & $\begin{array}{c}70,2 \\
13\end{array}$ & $\begin{array}{c}0,0 \\
00\end{array}$ & 1,489 & 0,122 & Linier \\
\hline
\end{tabular}

\section{Uji multikolinearitas}

Uji multikolinearitas bertujuan untuk memastikan bahwa tidak ada tejadinya hubungan multikolinear antara ketiga variabel bebas. Berdasarkan tabel 3 di bawah ini menunjukkan kedua variabel masingmasing memiliki nilai tolerance = $0,752,0,709$ dan $0,713(>0,1)$ dan nilai $\mathrm{VIF}=1,330,1,410$ dan 1,403 $(<10)$, sehingga dapat disimpulkan bahwa antar kedua variabel bebas tidak terjadi multikolinieritas.

Tabel 3

Hasil Uji Multikolinieritas

\begin{tabular}{lccl}
\hline \multirow{4}{*}{ Model } & \multicolumn{2}{c}{ Collinearity } & \\
\cline { 2 - 4 } & $\begin{array}{c}\text { Statistics } \\
\text { Tolera }\end{array}$ & VIF & \\
\hline $\begin{array}{l}\text { Komunikasi } \\
\text { Interpersonal } \\
\text { Guru }\end{array}$ & 0,752 & 1,330 & $\begin{array}{l}\text { Tidak terangan } \\
\text { multikolineritas }\end{array}$ \\
\hline $\begin{array}{l}\text { Student } \\
\text { Engagement }\end{array}$ & 0,709 & 1,410 & $\begin{array}{l}\text { Tidak terjadi } \\
\text { multikolineritas }\end{array}$ \\
\hline Efikasi Diri & 0,713 & 1,403 & $\begin{array}{l}\text { Tidak terjadi } \\
\text { multikolineritas }\end{array}$ \\
\hline
\end{tabular}

\section{Tabel 4}

\section{Hasil analisis regresi secara bersama-sama}

\begin{tabular}{lll}
\hline Variabel & F & Sig \\
\hline School well-being & 35,880 & 0,000 \\
\hline Komunikasi & & \\
Interpersonal & & \\
Guru & & \\
\hline Student & & \\
engagement & & \\
Efikasi Diri & & \\
\hline
\end{tabular}

Berdasarkan tabel 4 dapat dilihat bahwa nilai $\mathrm{F}=35,880$ dan taraf signifikan sebesar $\mathrm{p}=0,000(\mathrm{p}<0,01)$ yang berarti bahwa terdapat pengaruh yang sangat signifikan komunikasi interpersonal guru, student engagement dan efikasi diri terhadap school wellbeing. Hasil analisis secara umum hipotesis mayor yang diajukan teruji kebenarannya, bahwa terdapat pengaruh yang sangat signifikan antara komunikasi interpersonal guru, student 
engagement dan efikasi diriterhadap school well-being. Besar sumbangan variabel independen terhadap variabel dependen dapat diketahui dari hasil determinasi regresi pada tabel berikut:

Tabel 5

\section{Hasil uji analisis koefisien determinasi}

\begin{tabular}{lllll}
\hline Model & R & $\begin{array}{l}\text { R } \\
\text { squar } \\
\text { e }\end{array}$ & $\begin{array}{l}\text { Adjust } \\
\text { ed r r } \\
\text { square }\end{array}$ & $\begin{array}{l}\text { Std. } \\
\text { Eror } \\
\text { of } \\
\text { the } \\
\text { estim } \\
\text { ate }\end{array}$ \\
\hline $\begin{array}{l}\text { Analisis } \\
\text { koefisien } \\
\text { determinasi }\end{array}$ & 0,7 & 0,542 & 0,527 & $\begin{array}{l}4,107 \\
6\end{array}$ \\
\hline
\end{tabular}

Berdasarkan tabel 5 diketahui $\mathrm{R}$ square sebesar 0,542 dipersentasekan $(0,542 \times 100 \%=54,2 \%)$ artinya komunikasi interpersonal guru, student engagement dan efikasi diri secara bersama-sama berpengaruh terhadap school well-being sebesar $54,2 \%$ sedangkan sisanya $45,8 \%$ dipengaruhi faktor lain yang tidak diteliti dalam penelitian ini.

Tabel 6

Hasil uji hipotesis variabel komunikasi interpersonal guru dengan school well-

\begin{tabular}{llll}
\multicolumn{3}{c}{ being } & \\
\hline Variabel & Sig & Beta & $\begin{array}{l}\text { Zero } \\
\text { Order }\end{array}$ \\
\hline $\begin{array}{l}\text { Komunikasi } \\
\text { interpersonal } \\
\text { guru }\end{array}$ & 0,000 & 0,309 & 0,569 \\
\hline
\end{tabular}

Berdasarkan hasil analisis yang menguji pengaruh komunikasi interpersonal guru terhadap school well-being diperoleh nilai beta sebesar 0,309 dengan nilai signifikan 0,000 . Hal ini berarti $\mathrm{p}<0,01$ (sangat signifikan), sehingga dapat disimpulkan terdapat pengaruh komunikasi interpersonal guru yang sangat signifikan terhadap school well- being siswa. Sumbangan efektif (SE) komunikasi interpersonal guru terhadap school well -being siswa sebesar 17,6\%, diperoleh dari:SE(X1) \% $=$ BETAx RXY x $100 \%=0.309 \times 0.569$ $\mathrm{x} 100 \%=17.6 \%$. Berdasarkan hal tersebut komunikasi interpersonal guru merupakan variabel yang berpengaruh secara sangat signifikan terhadap school well-being pada siswa SMP Negeri 1 Semanu.

\section{Tabel 7}

Hasil uji hipotesis variabel student engagementdengan school well-being

\begin{tabular}{lccl}
\hline Variabel & Sig & Beta & $\begin{array}{l}\text { Zero } \\
\text { Order }\end{array}$ \\
\hline $\begin{array}{l}\text { Student } \\
\text { engagement }\end{array}$ & 0,027 & 0,189 & 0,522 \\
\hline
\end{tabular}

Berdasarkan hasil analisis yang menguji pengaruh student engagement terhadap school well-being diperoleh nilai beta sebesar 0,189 dengan nilai signifikan 0,027 . Oleh karena $p<0,05$ (signifikan), sehingga dapat disimpulkan terdapat pengaruh student engagement terhadap school well-being siswa. Sumbangan efektif student engagement terhadap school well-being adalah sebesar 9,9\% diperoleh dari: $\mathrm{SE}(\mathrm{X} 2) \quad \% \quad=\mathrm{BETA} \quad \mathrm{x}$ $\operatorname{RXY} \times 100 \%=0.189 \times 0.522 \times 100 \%=$ 9.9\%. Berdasarkan hal tersebut student engagement merupakan variabel yang berpengaruh secara signifikan terhadap school well-being pada siswa SMP Negeri 1 Semanu.

\section{Tabel 8}

Hasil uji hipotesis variabel efikasi diridengan school well-being

\begin{tabular}{lccl}
\hline Variabel & Sig & Beta & $\begin{array}{l}\text { Zero } \\
\text { Order }\end{array}$ \\
\hline $\begin{array}{l}\text { Efikasi } \\
\text { diri }\end{array}$ & 0,000 & 0,418 & 0,640 \\
\hline
\end{tabular}


Berdasarkan hasil analisis yang menguji pengaruh efikasi diri terhadap school well-being diperoleh nilai beta sebesar 0,418 dengan nilai signifikan 0,000 . Hal ini berarti $\mathrm{p}<0,01$ (sangat signifikan), sehingga dapat disimpulkan terdapat pengaruh efikasi diri yang sangat signifikan terhadap school well-being siswa. Sumbangan efektif (SE) efikasi diri terhadap school well-being adalah sebesar 26,8\% diperoleh dari:SE(X3) $\%=$ BETA $x$ RXY $\times 100 \%=0.418 \times 0.640 \times 100 \%=$ $26.8 \%$. Berdasarkan hal tersebut efikasi diri merupakan variabel yang berpengaruh secara sangat signifikan terhadap school well-being pada siswa SMP Negeri 1 Semanu.

Hasil analisis regresi terhadap kedua variabel bebas yaitu efikasi diri dan optimisme terhadap stres akademik mahasiswa didapatkan bahwa efikasi diri dan optimisme secara simultan berperan terhadap stress akademik mahasiswa. Berdasarkan hasil tersebut menunjukkan bahwa hipotesis pertama diterima sehingga variabel school well-being dapat diprediksi berdasarkan komunikasi interpersonal guru, student engagement dan efikasi diri. Secara bersamasama ketiga variabel bebas memiliki nilai $\mathrm{R}$ square sebesar 0,542dengan sumbangan sebesar $54,2 \%$ terhadap school well-being dan 45,8\% sisanya dapat dipengaruhi oleh variabel lain.Pada hipotesis kedua yang diajukan Berdasarkan hasil uji analisis regresi diperoleh pengaruh komunikasi interpersonal guru terhadap school well-being siswa adalah sebesar 0,176 atau $17,6 \%$ dengan nilai signifikan 0,000 . Oleh karena itu $\mathrm{p}<0,01$ (sangat signifikan). Hasil ini menunjukkan bahwa terdapat pengaruh komunikasi interpersonal guru yang sangat signifikan terhadap school well-being. Hal ini berarti semakin tinggi komunikasi interpersonal guru maka akan semakin tinggi pula school well- being siswa SMPN 1 Semanu Gunungkidul. Hal ini sesuai dengan hasil penelitianpenelitian sebelumnya[29]. Pada hipotesis ketiga yang diajukan berdasarkan hasil uji analisis regresi diperoleh pengaruh student engagement terhadap school well-being adalah sebesar 0, 09865 atau 9,9\% dengan nilai signifikan 0,027 . Oleh karena itu $\mathrm{p}<0,05$ (signifikan). Hasil ini menunjukkan bahwa terdapat pengaruh student engagement terhadap school well-being. Artinya penelitian ini membuktikan bahwa ada pengaruh signifikan student engagement terhadap school well-being siswa SMP Negeri 1 Semanu Gunungkidul. Pada hipotesis keempat yang diajukan berdasarkan hasil uji analisis regresi diperoleh pengaruh efikasi diri terhadap school well-being adalah sebesar 0,268 atau $26,8 \%$ dengan nilai signifikan 0,000 . Oleh karena itu $\mathrm{p}<0,01$ (sangat signifikan). Hasil ini menunjukkan bahwa terdapat pengaruh efikasi diri yang sangat signifikan terhadap school well-being. Artinya, penelitian ini membuktikan bahwa ada pengaruh yang sangat signifikan efikasi diri terhadap school well-being siswa SMP Negeri 1 Semanu Gunungkidul. Semakin tinggi efikasi diri siswa maka akan semakin tinggi pula school well-being siswa tersebut.

\section{Kesimpulan}

Berdasarkan hasil analisis data penelitian maka kesimpulan yang dapat diambil dalam penelitian ini antara lain yaitu: 1) Ada pengaruhyang sangat signifikan antara komunikasi interpersonal guru, student engagement dan efikasi diri secara bersamasama terhadap school well-being pada siswa SMP Negeri 1 Semanu. 2) Ada pengaruhkomunikasi interpersonal guru yang sangat signifikan terhadap school well-being pada siswa SMP Negeri 1 Semanu. 3). ada pengaruh student engagement yang signifikan terhadap school well-beingpada siswa SMP Negeri 1 Semanu. 4). Ada pengaruh efikasi diri yang sangat signifikan terhadap school 
well-being pada siswa SMP Negeri 1 Semanu,

\section{BIBLIOGRAFI}

Aisah, D. N. (2018). Hubungan antara pemenuhan Basic Psychological Needs dengan keterlibatan siswa dalam belajar pada sistem pembelajaran Full Day School. UIN Sunan Ampel Surabaya.

Alang, S. (2018). Komunikasi interpersonal guru dalam meningkatkan keaktifan belajar siswa kelas $X$ jurusan teknik sepeda motor di smk negeri 1 Parigi. Kinesik, 5(1), 1-11.

Alsa, A., Haq, A. H. B., Siregar, A. J., Kusumaningrum, F. A., Utami, H. D., \& Bachria, R. D. (2015). Menyusun Model yang Efisien dan Efektif dari DimensiDimensi School Wellbeing untuk Memprediksi Prestasi Belajar Matematika. Jurnal Psikologi, 42(1), 15-33.

Bandura, A. (1997). Self-efficacy: The exercise of control. New York: W. H. Freeman and Company.

Bandura, Albert. (1995). Self-efficacy in changing societies. Cambridge university press.

Devito, J. A. (2016). The Interpersonal communication book- 14th Edition. New York: Pearson Education Inc.

Duckett, P., Kagan, C., \& Sixsmith, J. (2010). Consultation and participation with children in healthy schools: Choice, conflict and context. American Journal of Community Psychology, 46(1-2), 167-178.

Firmanila, F., \& Sawitri, D. R. (2015). Hubungan Antara Efikasi Diri Akademik Dengan School Well-being Pada Siswa SMP Hang Tuah 1 Jakarta. Jurnal Empati, 4(2), 214-218.

Fredricks, J. A., Blumenfeld, P. C., \& Paris, A. H. (2004). School engagement:
Potential of the concept, state of the evidence. Review of Educational Research, 74(1), 59-109.

Gunuc, S. (2014). The relationships between student engagement and their academic achievement. International Journal on New Trends in Education and Their Implications, 5(4), 216-231.

Hongwidjojo, M. P., Monika, M., \& Wijaya, E. (2018). Relation of student-teacher trust with school well-being to high school students. Psikodimensia, 17(2), 162-167.

Huebner, E. S., \& McCullough, G. (2000). Correlates of school satisfaction among adolescents. The Journal of Educational Research, 93(5), 331-335.

Hurlock, E. B., Istiwidayanti, Sijabat, R. M., \& Soedjarwo. (2002). Psikologi perkembangan: Suatu pendekatan sepanjang rentang kehidupan. Erlangga, Jakarta.

Karyani, U., Prihartanti, N., Dinar, W., Lestari, R., Hertinjung, W. S., Prasetyaningrum, J., Partini, D. (2015). The dimensions of student well-being. Seminar PSikologi \& Kemanusiaan, 413-419.

Khatimah, H. (2015). Gambaran school wellbeing pada peserta didik program kelas akselerasi di SMA Negeri 8 Yogyakarta. Psikopedagogia, 4(1), 20-30.

Kraag, G., Zeegers, M. P., Kok, G., Hosman, C., \& Abu-Saad, H. H. (2006). School programs targeting stress management in children and adolescents: A metaanalysis. Journal of School Psychology, 44(6), 449-472.

Nanda, A., \& Widodo, P. B. (2015). Efikasi diri ditinjau dari school well-being pada siswa sekolah menengah kejuruan di Semarang. Empati, 4(4), 90-95.

O'Brien, M. (2008). Well-being and postprimary schooling. Dublin: NCCA.

Papalia, D. E., Old, S. W., \& Feldman, R. D. 
(2008). Human development (psikologi perkembangan). Jakarta: Kencana.

Rakhmat, J. (2009). Psikologi komunikasi. Bandung: Remaja Rosda Karya.

Reeve, J. (2005). How teachers can promote students' autonomy during instruction: Lessons from a decade of research. Iowa Educational Research and Evaluation Association.

Rianatha, L., \& Sawitri, D. R. (2015). Hubungan antara komunikasi interpersonal guru-siswa dengan selfregulated learning pada siswa SMAN 9 Semarang. Jurnal Empati, 4(2), 209213.

Roffey, S. (2012). Pupil wellbeing-Teacher wellbeing: Two sides of the same coin? Educational and Child Psychology, 29(4), 8.

Sabo, D. J. (1995). Organizational climate of middle schools and the quality of student life. Journal of Research \& Development in Education.
Sarwono, S. W. (2012). Psikologi remaja. Jakarta: P.T. Raja Grafindo Persada.

Setyawan, I., \& Dewi, K. S. (2015). Kesejahteraan sekolah ditinjau dari orientasi belajar mencari makna dan kemampuan empati siswa sekolah menengah atas. Jurnal Psikologi Undip, 14(1), 9-20.

Tian, L., Tian, Q., \& Huebner, E. S. (2016). School-related social support and adolescents' school-related subjective well-being: The mediating role of basic psychological needs satisfaction at school. Social Indicators Research, 128(1), 105-129.

Van Petegem, K., Creemers, B. P. M., Rossel, Y., \& Aelterman, A. (2005). Relationships between teacher characteristics, interpersonal teacher behaviour and teacher wellbeing. The Journal of Classroom Interaction, 3443.

Copyright holder :

Kuswoyo, Nurul Hidayah dan Ahmad Muhammad Diponegoro (2021).

First publication right :

Jurnal Syntax Transformation

This article is licensed under: 